\title{
The Diverse Functions of Symbolism in Maqamat Imam Al- Suyutiy
}

Mohamad Faisal Kamis, Pabiyah Toklubok, Nik Farhan Mustapha, Wan Muhammad Wan Sulong, Kamariah Kamarudin \& Haliza Abdul Rahman

To Link this Article: http://dx.doi.org/10.6007/IJARBSS/v11-i19/11737 DOI:10.6007/IJARBSS/v11-i19/11737

Received: 02 October 2021, Revised: 01 November 2021, Accepted: 24 November 2021

Published Online: 17 December 2021

In-Text Citation: (Kamis et al., 2021)

To Cite this Article: Kamis, M. F., Toklubok, P., Mustapha, N. F., Sulong, W. M. W., Kamarudin, K., \& Rahman, H. A. (2021). The Diverse Functions of Symbolism in Maqamat Imam Al-Suyutiy. International Journal of Academic Research in Business and Social Sciences, 11(19), 275-288.

Copyright: (c) 2021 The Author(s)

Published by Human Resource Management Academic Research Society (www.hrmars.com) This article is published under the Creative Commons Attribution (CC BY 4.0) license. Anyone may reproduce, distribute, translate and create derivative works of this article (for both commercial and non-commercial purposes), subject to full attribution to the original publication and authors. The full terms of this license may be seen at: http://creativecommons.org/licences/by/4.0/legalcode

Special Issue Title: Youth and Community Wellness, 2021, Pg. 275 - 288

Full Terms \& Conditions of access and use can be found at http://hrmars.com/index.php/pages/detail/publication-ethics 


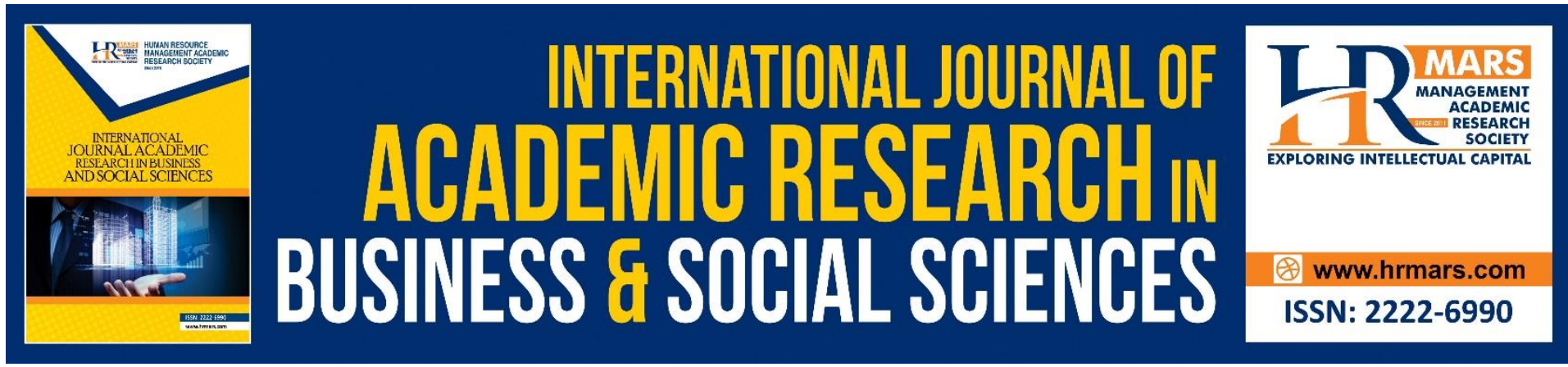

\title{
The Diverse Functions of Symbolism in Maqamat Imam Al-Suyutiy
}

\author{
Mohamad Faisal Kamis ${ }^{1,2}$, Pabiyah Toklubok ${ }^{1,2, a}$, Nik Farhan \\ Mustapha ${ }^{1,2}$, Wan Muhammad Wan Sulong ${ }^{1,2}$, Kamariah \\ Kamarudin ${ }^{1,2}$ \& Haliza Abdul Rahman ${ }^{1,3}$ \\ ${ }^{1}$ Institute for Social Science Studies, Universiti Putra Malaysia, 43400 Serdang, Selangor, \\ Malaysia, ${ }^{2}$ Faculty of Modern Languages and Communication, Universiti Putra Malaysia, \\ Serdang, Selangor, ${ }^{3}$ Faculty of Medicine and Health Sciences, Universiti Putra Malaysia, \\ Serdang, Selangor \\ Email: pabiyah@upm.edu.my
}

\begin{abstract}
Elements of symbolism in literary works are one of the essential elements discussed in any academic research. Symbolism is a medium to represent ideas and messages that the author wants to convey in his work. Meanwhile, Maqamat is a literary work which is loaded with symbols through the symbolic style of language and also has a message to convey. Therefore, this study is conducted to identify and analyse the functions of symbols in Maqamat Imam al-Suyutiy (MIS). This research is a qualitative study that uses the method of textual analysis. The research data was selected based on the elements of symbolism contained in the text of the speech taken directly from the five maqamat. In order to achieve the set objectives, the Nazm theory established by Abd al-Qahir al-Jurjaniy was used in this study. The analysis of context and co-text was conducted for all research data using this Nazm theory. The results showed that there were symbols such as flowers, fruits, gems, and fragrances used by the author. These symbols had several functions such as depicting the bad attitude of the government leaders, criticising the attitude of the members of the society, avoiding punishment by the rulers, expressing the discomfort of the MIS author about the political situation, and depicting the character of a person.
\end{abstract}

Keywords: Symbolism, Maqamat, Imam al-Suyutiy, Arabic Prose, Nazm Theory

\section{Introduction}

In studying a work of literature, a linguist will usually prefer to look at how an author conveys an idea in a certain way or style, whereas a literary researcher prefers to look at the effect of aesthetic value achieved through the use of language. Questions relating to the use of symbols in literary texts are often debated by linguists regarding the extent members of society are able to digest the thoughts that the author attempts to convey. In addition, literary researchers are not spared from looking at the function and importance of using symbols in literary works that exist to embellish the style of language in the work that is presented to the public. Therefore, a study on the elements of symbolism in a literary work should be closely 
considered especially when it involves literary text that substantially uses implicit language which is difficult to understand directly. Arabic literary works such as poems, narratives, novels and maqamat often become the focus of Eastern and Western researchers for the last several years. The art of maqamat generally, is one of the forms of Arabic prose which has existed since the third century Hijrah. In terms of etymology, the word maqamat originated from the word qama (قام) which means to stand up or rise and maqam is the noun for place (اسم المكن) for qama which has the meaning of place to stand (Ibn Manzur, 2003). Maqamat is also the plural of the word maqam (مقام) (Ibn Manzur, 2003). Whereas in terms of terminology, maqamat is one of the genres of Arabic prose which has elements of artistic aesthetics and its own distinctive basic format. The author intends to present whatever ideas required in certain issues, while also revealing the greatness and distinction of the author in expressing words. Every word and idea conveyed usually represents the author's preferences and direction. The text of the maqamat contains various symbolic and figurative language elements that have a role in presenting the author's ideas and messages regarding a certain issue (Al-Darubiy, 2001).

The maqamat is an example of Arabic prose text that is abound with messages that can become material for research especially regarding the use of symbols which is closely related to the ideas and thoughts that the author is trying to convey. The choice of literary prose such as the maqamat text is important because the literature itself is Fann Qauqliy (art of words) which contains value, that is in terms of verbalization, content and special features (Darwish, 2008). Therefore, this is significant and merits study to highlight the diversity of functions and roles of symbols in expressing the messages and ideas found in Maqamat Imam al-Suyutiy (MIS), specifically by applying the Nazm theory in analysing every text of speech that contains symbolism elements based on the storytelling narrative found in MIS. Furthermore, choosing this theory will also enable descriptive and explicit interpretation regarding the existence of symbols in the speech text composed by Imam al-Suyutiy in his maqamat works. Therefore, the objectives of this study are to:

- Identify the type of symbolism used by the Imam al-Suyutiy in his maqamat

- Analyse the function of symbolism in Maqamat Imam al-Suyutiy

\section{Literature Review}

Elements of symbolism are often used by creative writers in their works of art. Since long ago creative arts writers have made various natural resources as elements of symbolism in forming the storytelling narrative that is interesting and channels a specific message to the reader. Symbolism in literary works means words or phrases used by a writer to explain something, a situation or an event that has a different or deeper meaning (Nik Hassan Basri, 2005). According to Maharam (2015) the environment is among one of the elements of symbolism widely used by literary authors in their writing. The use of words such as flowers, fruits, trees, water and others in literary works prove the use of natural elements by the author (Diaul, 2018). In fact, Zurinah (2010) stated that "artists with sensitive feelings are very closely connected to the environment. This is because they assume that nature is alive and that growth, rocks and flowers are living beings".

Highlights of past studies have found that natural resources such as flowers, fruits, fragrances and others play a very important role in the Arab society. This is because the classic Arab society is in a process of interaction, interpretation and integration with the environment especially the Arab society during the period of Ignorance (Jahiliah) and Islam. Arabic literature authors whether of poetry or prose often used natural elements in their work 
and this requires accurate research and observation to see the exact connection between the natural element and the life of the Arab society so that the interpretation process that takes place can be accepted and understood based on the context of time, place, tradition and culture of the Arab society at that time. Interpretation here means, every element of nature used as a symbol is presumed to have a larger meaning than their true function. The author also perceived or integrated nature as a resemblance for himself or the community around him (Al-Ghubariy, 2013).

Arab society generally experienced a significant sociocultural and religious change especially after Islam ruled the Arab lands (Uqayyib, 2018). The writing of Arabic literature greatly depended on the local community setting including nature. Thus, the use of environmental symbolism does not only have the role of giving life to the setting but also to enhance the literary work from the aspect of highlighting the author's thoughts and wisdom that requires the reader to interpret the meaning and purpose that is trying to be conveyed. This is because the use of natural elements in Arabic prose especially is intricately connected to the thinking of the Arab community that always uses natural elements such as kinayah, istiarah and tashbih when discussing a certain matter (Al-Darubiy, 2001).

A review of past literature also found that the use of natural elements as symbols is not only found in Arabic literary works. In fact, all the world literature including Malay literature often uses natural resources as a symbolism in their work. According to Salinah (2017), the symbolism of nature is often used to express various ideas and purposes about practices, beliefs and culture of the life of the Malay community. Every event and matter that takes place around human life is inseparable from nature. Salinah (2017) also stated that a Malay literary work produced by the author should contain messages that are useful to the audience. This is because the culture of the Malay community has traditionally used the natural environment as a source of education and formation of human personality since ancient times. The traditional Malay community sees nature as a resource that contains various meanings that can be used as a guide, a lesson and also a mentor for survival. This can be identified when the Malay literary author used natural resources through various forms and elements. Therefore, creative authors combine all their creativity and imagination in producing their work so that it can be a source of teaching to the public. This creativeinnovative process is also present in the form of experience, surroundings and personal background, for example (Salinah, 2017).

Diaul (2018) stated that literary works are actually the human personal expression that encompasses experience, thought, feelings, ideas, spirit and also confidence. This is almost a similar view to Wellek and Warren (1995). Both views presented the argument that "literature is a creative activity and a work of art that is able to add wisdom in life". However, an author expresses elements that are different from one another, appropriate to their own distinctive work. The use of symbolism in literary works has a significant function and role even more so as the use of elements of symbolism is related to nature. Generally natural elements such as flowers, fruits, fragrances, trees and others have a specific meaning and philosophy such that the presence of this natural element creates a symbol that is useful to developing life. It is in this context that roles are required from literary experts such as novelists, short story writers, poets and artists to appreciate and interpret nature from a view that can lead the reader to a different meaning and thought (Diaul, 2018).

Among the writers of Arabic prose who often used natural resources as symbols for specific meanings and messages was Imam al-Suyutiy. al-Suyutiy was one of the most prolific Arab scholars who produced hundreds of writings that encompassed various disciplines of 
knowledge, amongst them the art of maqamat (al-Darubiy, 2001). Maqamat Imam al-Suyutiy (MIS) for example is one of his works that extensively uses symbolic and figurative language styles in conveying various issues and community problems. According to al-Ghubariy (2013) the elements of symbolism in MIS must be looked at from various points of views specifically by combining with the science of literary criticism, history of Arabic literature, the science of faith, mysticism (tasawuf) and others. This is because MIS is a work that is laden with literary language style and presents a different style of writing maqamat compared to the writing of the earlier maqamat. Dayf (2000) stated that MIS is a work of quality that was produced towards the end of the Mamalik government ruling era in Egypt. Whereas Salim (1962) stated that MIS is an interesting piece of work to discuss because Imam al-Suyutiy did not write it unless he had given careful thought to present the idea in a scholastic and creative manner such that there are several differences compared to the works of other earlier scholars and intellectuals. Among the differences are the content of the story that was presented is something realistic such as his criticism of the Mamalik Jarakisah government during the eighth century Hijrah (al-Darubiy, 2001). al-Suyutiy in several instances represented his story through nature such as flowers, fragrances, fruits, precious stones, nuts and many more (Anqar, 2017). Thus, MIS if scrutinised from the angle of use of natural resources has a significant difference especially in the aspect of the existence of symbolism in conveying the contents of the story which is largely based on reality and not imagination (Anqar, 2017).

Besides that, al-Shak'ah (1981) in his commentary on MIS explained that the work had virtue and importance that should be given attention to and shared widely to the lovers of language and literature after having done an in-depth process of review (tahqiq). Based on several commentaries and views of the above scholars, it can be concluded that the MIS work had its own distinctive character, which ought to be studied for the use of elements of symbolism that was presented besides its function and role in conveying the messages and thoughts to the reading audience. Meanwhile, Sulaiman (1989) stated that the MIS work is not only rich in elements of symbolism and literary language style but also encompasses an interesting storytelling narrative as there are phrases from the al-Quran, the hadiths of the Prophet PBUH, Arabic poetry, and pearls of wisdom used by al-Suyutiy in his writings. Several scholars such as Ibn Iyyas, Ibn al-Imad and al-Katani often praised and used Imam al-Suyutiy's work as a reference and model in their writing (Anqar, 2017). The MIS works were actually not collated into a specific book but was written based on the various events that took place in the Egyptian community and the life of Imam al-Suyutiy himself. Therefore, there are views that state that this is the reason his writing of maqamat took a long period of time (Dayf, 2000).

Generally, the form of storytelling narrative of the art of the Arabic maqamat is divided into several types such as hikayah, makdubah, maqalah and izah (al-Ghubariy, 2013). However, if observed, most of the stories in MIS is in the form of maqalah and short stories. The content presented in MIS if comprehensively reviewed, actually encompasses various topics of debate. Hasan (1974) stated that MIS is an encyclopaedia of religious and world knowledge that debates every matter that benefits and teaches mankind. Whereas al-Shak'ah (1981) stated that MIS is a library of Arabic literature that has a beautiful style of language such as the use of symbolism as well as presenting interesting story content. Therefore, the production of MIS from almost five centuries ago as a literary work is not something common but has its own status and distinctive character especially when touching on the beauty of the style of language used and the thoughts that its author was trying to convey. 


\section{Methodology}

This study is a qualitative study using the text analysis method based on the literary work Maqamat Imam al-Suyutiy (MIS). The research materials were five maqamat composed by al-Suyutiy during the tenth century Hijrah. The five maqamat were reviewed in detail by two Arabic linguistic and literary experts, Abd al-Ghaffar Sulayman al-Bandariy and Muhammad al-Said Basyuniy Zaghlul. Both these scholars collected five of al-Suyutiy's maqamat based on old manuscripts found in several famous libraries such as the Leiden University Library in the Netherlands, the Royal Library, Rabat, Morocco, and the National Library in Paris. The five maqamat are Maqamah Fustuqiyyah, Maqamah Tuffahiyyah, Maqamah Yaqutiyyah, Maqamah Wardiyyah and Maqamah Miskiyyah. These five maqamat were selected because its existence was agreed upon by MIS researchers since then until today (Al-Hasanat, 2013). For this research, a book revised and annotated by al-Bandariy and Zaghlul was used (1986). The research data was chosen based on the elements of symbolism contained in the text of speech taken directly from the five maqamat. The analysis of the context and co-text was performed on all research data using the Nazm theory by (Al-Jurjaniy, 1994).

The Nazm theory which was introduced by Abd al-Qahir al-Jurjaniy (1994) is a theory that emphasises the meaning of context and co-text. The context and co-text meaning meant by al-Jurjaniy (1994) in his theory is the true meaning that is obtained resulting from the detailed scrutiny of the arrangement of words that form a speech text by referring to all the context behind and around the speech text whether in a linguistic or non-linguistic context such as time, place, tradition, culture and many more (Lashin, 1980).

This research is focused on debate and overall analysis which is related to the elements of symbolism which were used by Imam al-Suyutiy in presenting a matter or event that occurred during his time. Every symbol contained in the MIS speech text actually has a specific idea, message and thought. Research data was taken directly from the text of the maqamat and carefully analysed to attain the purpose outlined. Each data that contained elements of symbolism was analysed and presented descriptively and explicitly based on the meaning of context and co-text.

\section{Findings and Discussion}

The following are the elements of symbolism contained in the speech text of Maqamat Imam al-Suyutiy (MIS).

\section{Ward, Yasamin and Narjis}

The author of MIS had used three types of flowers, which are Ward (also known as the rose), Yasamin and Narjis as symbols and elements of symbolism in his storytelling narrative to the reading audience. This can be seen by the text of the speech as follows:

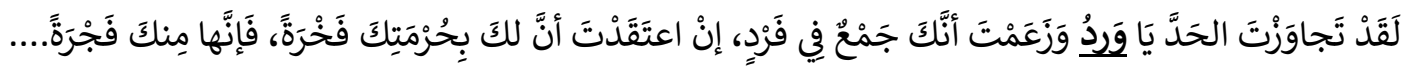 Verily you have transgressed oh Ward. You claim that you are many in one. Should you consider your glory a pride, indeed that is a disgrace to you... ( $\mathrm{p}$. 84).}

In the text of the speech above, the author of MIS had recorded the words of the flower Narjis to the flower Ward. The situation behind this speech is a reception that was attended by several government dignitaries who were symbolised by several types of flowers found in the Arab community, specifically in Egypt. Based on the analysis of the meaning of 
context and co-text the author has presented a portrayal of attitude and morals of some government leaders in conveying their words through the use of symbolising flowers, specifically the leaders who long for position and status. This is based on the context of the dialogue that took place which is presented by the expression of words which have elements of contempt and demeaning one another. Reviewing the text of the speech that contained the elements of symbolism above, the study found that the particle lam (ل) was combined with the particle qad (قَ). Both these particles are particles of emphasis (tawkid) that function to emphasise and reinforce the news to be conveyed. The use of the two tawkid particles in this expression signals that Narjis was extremely angry towards Ward that is presumed to have overstepped its limits in praising and exalting itself. The claim by Ward which was excessive relating to itself as if only it was the best and most glorious did not sit well with Narjis. Therefore, the author of MIS used the tawkid particle to explain the situation.

The use of tawkid in the context of the Arab community is not something new. In fact the al-Quran often uses this type of language style (uslub) to emphasise and reinforce something. According to al-Samarra'iy (2009) the Arabs use tawkid in situations that require the use tawkid, not frivolously or for fun. Uslub or the tawkid language style has several types based on the situation and attitude of the listener. The selection of the tawkid particle in a speech is influenced by the listener's protest or disobedience regarding a news that is conveyed. Therefore, when the flower Narjis used these words, it means that it wants to protest the claim made by the flower Ward as well as emphasise that the attitude of the flower Ward in praising itself is not wise, such as what is found in the following speech:

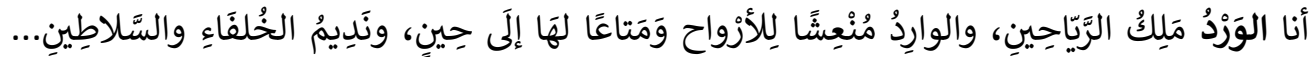

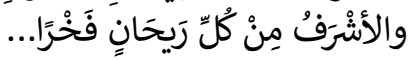

I am Ward, king of all the fragrant flowers and I appear as a refresher and soother to all souls until the appointed time. I am also a close companion to the caliphs and sultans .... and I am the most glorious and the pride of all types of flowers...( p. 82).

In the text above, the author of MIS used the rose (Ward) symbol to represent the attitude and behaviour of several government leaders of the Mamalik Jarakisah rule during the tenth century Hijrah (al-Darubiy, 2001). The rose is as symbol of a leader who is proud and arrogant. Thus, the rose was rebuked by several other flowers as seen in the speech text above. The word fajrah in the text that is used by the author shows that the rose was criticised by the other flowers that did not agree with the words and speech made for claiming that it had many advantages and contributions compared to the other flowers (Sulaiman, 1989). According to al-Darubiy (2001) the rose in the dialogue found in this maqamat story above had humiliated the other flowers found at the same reception. This situation and surroundings actually represent the fight for power that happened during the Mamalik Jarakisah government rule after the death of Sultan Qaytbay. Meanwhile, the author of MIS also stated:

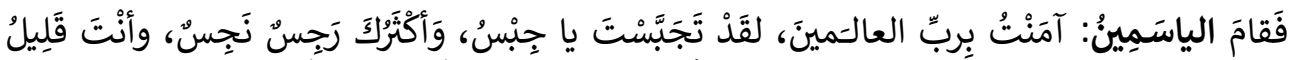

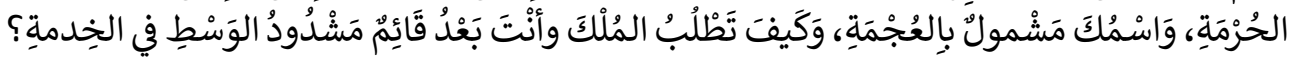

$$
\begin{aligned}
& \text { And the flower Yasamin stood up and said: I believe in the god of the universe, } \\
& \text { truly you are arrogant o haughty disgraceful one. Most of you are vile and }
\end{aligned}
$$


unclean and you are less respected. Your name is filled with vagueness, so how can you ask for power whereas you are still young to serve? (p. 86).

Based on the arrangement of the words contained in the speech text above, the author of MIS had used the dialogue technique to portray the existence of a discussion among the flowers at a reception. The use of a second pronoun which are the particles $t a^{\prime}(ت \bar{ء})$ and kaf (كاف) in the text above clearly shows that the flower Yasamin is directing its words to the flower which was speaking before it, which was Narjis. The author used the particle $f a^{\prime}$ (ف) in the early part of the text to show the existence of continuity from the dialogue before. The particle $f a^{\prime}$ (فَاء) is one of the 'ațf (العَطْف) letters used as a discourse marker or bridge to the plot of a story. This means before the flower Yasamin stood up and spoke, there were other flowers before it that had already done the same. The MIS author also presented the Jinas Mudari' element to criticise the attitude and claim by the flower Narjis that was excessive in

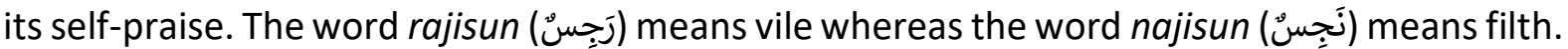

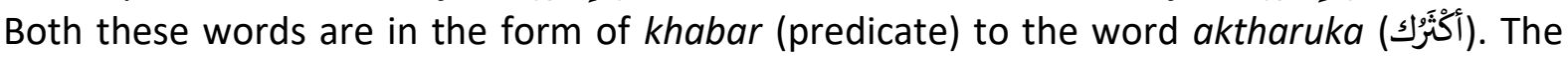

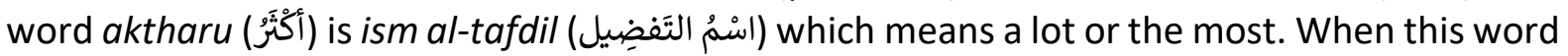
is supported by the second pronoun which is $k a$ (5)), this gives the meaning that most of the Narjis flowers are vile and unclean.

Hence, the flower Yasamin wanted to state that the attitude and morals of the flower Narjis are not suitable to shoulder the responsibility as the leader of a country. The author

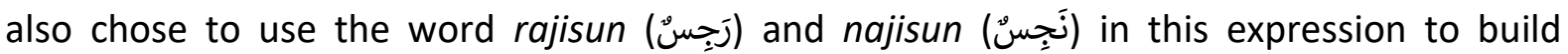
compatibility of sound and speech even though there are differences to the first letter. The beauty in this word is that it also actually gives a clear and easy to understand meaning about the ugly traits found in the flower Narjis according to the view of the flower Yasamin. The analysis of the meaning of the context and co-text also found that the setting to the speech text above actually refers to a reception that gathered the dignitaries who hoped to replace the current sultan or king. However, the MIS author had used the symbolism of several types of flowers such as Ward, Narjis, Yasamin and others as symbolic to humans who fight over status and position.

Based on the analysis conducted of the context and co-text meaning, the research found that the symbolism of several types of flowers which was used was actually a group of government dignitaries who had agreed to hold a reception to choose the replacement for the sultan who had passed away. Every dignitary had attended to present their argument and reasons why they should be elevated and chosen to replace the sultan. Therefore, all the dignitaries who were symbolised by these flowers, had stood up one by one to deliver their speech and words. Until when it came to the turn of the flower Yasamin, which got up and threw criticism to the flower Narjis with words which were harsh and sharp. In fact, Yasamin also stated that Narjis is a type of flower that is unknown and foreign to the Egyptian Arab community which refers to the immigrants who resided in Egypt around the eighth century Hijrah. The immigrants included the Turkoman, Kurds, Romans, Turks, Circassians, and those from Caucasus (Marsot, 1985). The symbolism used by the MIS author in the speech text above shows that the flower Yasamin delivered the speech to its opponent during a leadership crisis which happened during the time of Imam al-Suyuțiy (Al-Ghubariy, 2013). According to al-Darubiy (2001), the political crisis impacted the Mamalik Jarakisah government during the middle of the ninth century Hijrah. This event is portrayed by the MIS author in his work by placing the narrative of a collection of several types of flowers including Yasamin which were competing and fighting for the position of head of the country to the 
extent of showing bad attitude and morals. Hence, the use of flower symbolism is identified to criticise the temperament and behaviour of several dignitaries who were greedy and hasty in the matter of succession of the sultan. They were portrayed by the MIS author as men who were crazed for power and so greedy to the extent that they were willing to insult and belittle others (Sulaiman, 1989).

\section{Zabad and Za'faran}

Zabad and Za'faran are two types of fragrances which are often used by the Arab community since long ago. In fact, both fragrances are also made gifts for a special person because of their fragrant scent and are difficult to come by. Therefore, the MIS author took the opportunity to use Zabad and Za'faran as symbols in his maqamat story as stated in the speech text as follows:

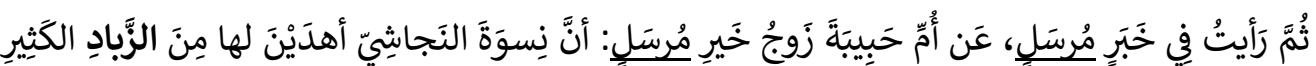

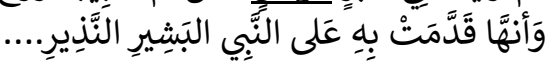

And then I saw in the khabar mursal from Ummi Habibah the wife of the best messenger (wife of the prophet Muhammad PBUH) stating: and so the women of al-Najashiy had gifted to her several Zabad. And she gave it to the prophet Muhammad PBUH the bringer of good news and giver of reminders... (p. 113).

Based on the analysis of the meaning of context and co-text conducted, the word thumma (ثُمَّم) in the speech text above clearly shows that the author had narrated about the benefits and features of fragrances other than Zabad in the earlier sentences. This is because the word thumma (ثُمَّمَ) in etymology means later, whereas according to the grammatical meaning, that particle is one of the 'ațf (العَطْف) letters that refer to a general discourse marker. This particle is used to connect several stories which are related according to sequence. The MIS author then stated using a past verb through the oral of an imam, which is ra'aytu (َأيتُ). The past verb used clearly shows that the imam had seen and found the benefits of Zabad in the alQuran and Hadith of the Prophet PBUH, authenticated athar of the companion and found it in the khabar mursal. Whereas the word khabar خَبِِ) when featured with the word mursal (مُرسَلِ will form something specific which is the news is only characterised as mursal and not something else. The word mursal also functions to explain the feature of the news that is required by the author. Hence when these two words combine, it will form a specific terminology which is found in the discipline of 'Ulum al-Hadith.

Through the analysis conducted, the research found that the expression above is intended to state that the Zabad fragrance is only found in khabar mursal. Whereas the three fragrances stated by the author earlier, which are Misk, 'Anbar and Za'faran are found in many narratives of the hadith or news whether its status is authenticated or hasan. The author did a comparison of the four types of fragrances based on the benefits and the law regarding its use taken from the al-Quran and sunnah of the Prophet PBUH. This is clear when he produced a hadith narration of Ibn Abi Dunya that the Prophet Muhammad PBUH has said:

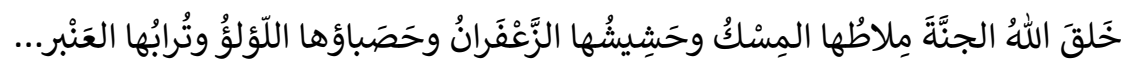

Allah SWT has created a heaven with its walls made from Misk and its grass from Za'faran and its rocks from Lu'lu' and its grounds from 'Anbar ... (alSuyutiy, 2005: 403). 
Whereas Zabad which was mentioned by the author is only mentioned in khabar mursal, but the context is set in the story of the women of al-Najashiy who had gifted to Ummi Habibah the said fragrance. Ummi Habibah then gave the gift to the Prophet PBUH to use. However, this khabar mursal is not as strong as authenticated hadith or hasan in terms of its proof. It can be seen here, it is as if the author wanted to give a comparison of the position and prestige of Zabad compared to Misk, Za'faran and 'Anbar. This can be seen in his expression as follows:

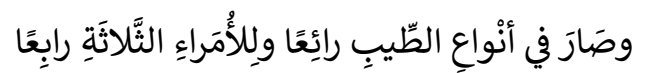

Thus Zabad is included into the types of attractive fragrances, and among the three leading fragrances it is the fourth ... (p. 114).

Based on the analysis conducted on the speech text which had the element of symbolism Zabad, the MIS author actually wanted to present a comparison of character and personage of the people during his time. The Zabad fragrance became the comparison for several other fragrances such as Misk and Za'faran. The research found that Zabad is a symbol of the character and the position of a common person in the society although having benefits and privileges. This can be identified through the comparison done by the MIS author by presenting the hadiths of the Prophet PBUH as above. One who has character and special position in the community is symbolised by Za'faran by the MIS author. This can be seen in the following speech text:

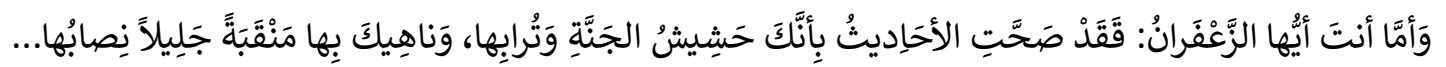

And there you are o Za'faran: Verily it is true that several of the Prophet PBUH hadiths that you are the grass in heaven and its ground hence it is enough for you that glorious privilege ... (p. 112).

Through the speech text above, the MIS author has mentioned that Za'faran is found in the hadiths of the Prophet PBUH that has the status of authenticated. Unlike Zabad which is only found in khabar mursal. Fundamentally, authenticated hadiths have significant differences from khabar mursal in terms of sanad and proof as well as istinbat law. According to the discipline of the knowledge of hadiths, the authenticated status in the narration of hadith has a high position in the process of issuing law whether that law is related to creed or jurisprudence (figh). Whereas khabar mursal is in the category of weak hadith (hadis daif) that can only be used as a support in terms of the benefits and encouragement of a practice or in terms of threatening to do a practice. This difference in status actually represents the difference in one's character and position in a community. The MIS author deliberately used the symbolism of two types of fragrances which are often used by the Arabs in their daily life which are Zabad and Za'faran to show the differences in class and position of someone who has personage and privilege in society. The function of using this symbol is to portray character and personage of an individual who has the best qualities such that he is considered special.

\section{Utrujjah}

The Utrujjah is a type of fruit found in Arab countries. Utrujjah is almost like a lemon and contains various nutrients for the health of the human body. Through the MIS work, al-Suyutiy also used the symbolism of the utrujjah fruit in conveying his messages and ideas to the 
community audience. Among the speech texts which contain elements of symbolism of the utrujjah fruit is the verses from a poem as follows:
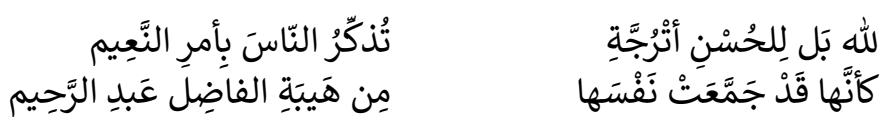

In the name of Allah truly the goodness of the utrujjah fruit reminds mankind of the tales of the heaven al-Na'im, as though it has combined itself with the greatness of al-Fadil 'Abd al-Rahim... ( p. 53).

The MIS author had penned the above poem in the context of discussing the greatness and the distinctiveness of the utrujjah fruit. This fruit has many advantages and benefits for humans including increasing appetite, reducing phlegm in the throat, lessen headaches and nausea, prevent diarrhoea and others (al-Suyutiy, 2008). In this poem there are several particles and words which are arranged in one nazm to state the idea or specific message to the reading audience. The author started off his bait with adat al-qasam which is the particle lam (ل), then there is tawkid bal (بل), the words husn, utrujjah, the word phrase "remind mankind" and details of al-Naim. Next in the second verse, the poet tries to relate the benefits and distinctiveness found in the utrujjah fruit to the greatness of a person named al-Fadil Abd al-Rahim. According to Ibn Khallikan (1994) al-Fadil Abd al-Rahim was a minister during the time of the rule of the sutan Salah al-Din al-Ayyubiy. His real name was Abd al-Rahim bin alQadi al-Ashraf Baha' al-Din and known by the nickname al-Qadi al-Fadil.

The use of uslub al-qasam and tawkid in the poetry verses above is to emphatically state that the utrujjah fruit has benefits and nutrition which are very special. The author used the particle lam (ل) and (بَل) as an emphasis for the message that is to be presented which is the goodness of the utrujjah fruit is able to remind mankind to the heaven of Allah SWT which is filled with many wonders. The word amr (أمْر) which is supported by al-Na'im (النَّعيم) has formed a wider meaning. This is because the word amr (أمَر) is a derivative noun from the basic word amara (أمَرَ) which means matter, business, affair, detail, order, direction and event (Umar et al., 2008). Therefore, when this word is made a mudaf to the word al-Na'im (النَّعيم), we can understand that the author wanted to portray matters relating to heaven which has every form of enjoyment and delicacies that is often dreamt by humans. The element of symbolism exists when the MIS author stated the goodness and the deliciousness of the fruit symbolising the pleasures that will be experienced by those who will reside in heaven. However, the symbolism that the MIS author tried to portray had excessive elements as the utrujjah fruit is considered able to remind and visualise to the community about the beauty of the heaven al-Na'im. Whereas the pleasure and beauty of heaven is incomparable to any being created by Allah SWT. At the same time, the benefits and distinctiveness of the utrujjah fruit presented in the poetry verses above also symbolises the greatness and the distinctiveness of a famous writer in the mid sixth century Hijrah that is Qadi al-Fadil. He was a minister during the rule of sultan Salah al-Din al-Ayyubiy (Marsot, 1985). He was very well known in the field of writing such that he was praised by sultan Salah al-Din al-Ayyubiy. In fact it was narrated that the sultan will not give a command or a decision regarding his administration unless after meeting and discussing with al-Qadi al-Fadil (Marsot, 1985).

Reviewing the analysis of the meaning of context and co-text in the poetry verses that contain the symbolism of the utrujjah fruit above, the research found that the MIS author had formed several important meanings that he wanted to state to the reading audience. First, the MIS author tried to symbolise the enjoyment in heaven by the benefit and distinctiveness 
of the utrujjah fruit which is often used by the Arab community in their daily life. Second, the MIS author also symbolised the utrujjah fruit that has several specialties with a famous scholar during the time of Ayyubiyah government, that is Qadi al-Fadil. Hence, the function of using the elements of symbolism above is to portray the pleasure and enjoyment which will be obtained by those who reside in heaven and also highlight the character and personage of someone who is great in the community.

\section{Yaqut}

Based on the analysis conducted, the research also found that the MIS author had used Yaqut as the symbol for the perfect human. The Yaqut precious stone has beautiful and attractive features that many people, man or woman, use it as a decoration in necklace lockets and rings. Generally Yaqut has many types, colours, shapes and forms. Therefore, the MIS author has used the Yaqut precious stone as a symbol for a special human as found in the following speech text:

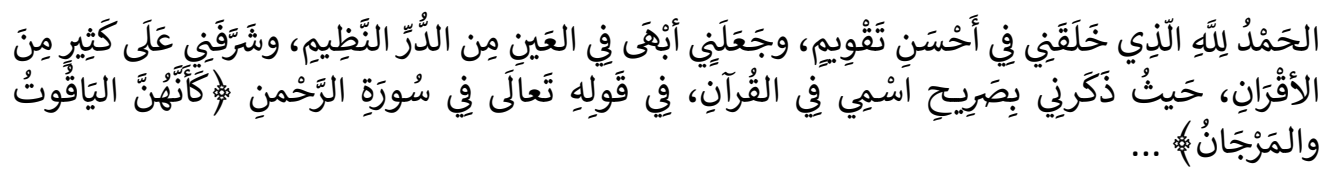

All praise be to Allah who has created me in the best form and made me the most beautiful among beautifully arranged precious stones. And then glorifies me above my many companions as He has mentioned me by name clearly in the al-Quran as He says in surah al-Rahman As the angels are the stones Yaqut dan Marjan 率... (p. 67) .

The expression text above stated by the MIS author as an introduction to the tale about seven precious stones which were competing amongst themselves by stating about their own advantages until they forgot the purpose of their creation for this world. Through the analysis of the context and co-text, the research found that the MIS author presented an initial portrayal of the main content that the author wanted to present in Maqamah Yaqutiyyah as a whole. Hence when the author started the phrase above with the word arrangement الحَمْدُ لِلَّهِ التّنِي خَلَقَنِي فِي أَحْسَنِ تَقْوِيمِ this clearly shows an acknowledgement and admission by a servant to the greatness of his god. The word alhamdu (الَحمْيم) has the particle disposition alif lam al-ta'rif that signals to the meaning perfection (al-Samarra'iy, 2009). It is as if the author wanted to say that all praises or exaltations can only be given to Allah SWT.

Then the word ahsana (أحسنَن) present with the pattern ism tafdil and supported by the word taqwim (تَقْويم) and forms a name phrase which has the meaning the best creation.

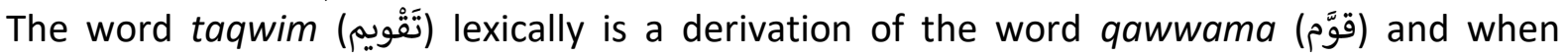
qawwama almu'awwij (قوم المُعَوَّج) is mentioned it means to correct it and to remove its flaws (Ibn Manzur, 2003). al-Darubiy (2001) when interpreting the word taqwim (تَقْويم) in surah alTin verse 4 , stated that the meaning of this word is the best creation. The best creation in surah al-Tin actually refers to the creation of mankind. Whereas the best creation stated in the phrase above refers to precious stones. It is as if the MIS author wanted to make the precious stones as symbols for the creation of humans. The beauty and splendour found in precious stones especially Yaqut symbolised the perfection found in humans specifically the mind, which is not bestowed upon other creatures. Similarly when the author used the phrase abha fi al-'ayn (أبهى في العين) which shows the meaning the most beautiful to behold. From the arrangement of these words, it can be understood that Allah SWT has created humans so 
beautifully and perfectly as the beauty and splendour of precious stones in the eyes of humans. The name phrase al-durru al-nazim (الدرُّ النظِيم) comprises an adjective and mawsuf which clearly presents about precious stones which are usually carefully arranged and set in one setting to make a necklace. The author then used the combination of words wa sharrafaniy 'ala kathirin min al-aqran (وشََرَفْنِي عَلَى كَثِيرٍ منَ الأقَرَانِ) which clearly shows that Yaqut was created and glorified more than other precious stones just like Allah created human beings and glorified by Allah SWT compared to other creatures. This is in line with the words of by Allah SWT which reads:

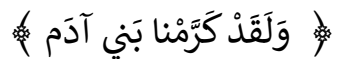

And verily we have glorified the children of Adam ... (Surah al-Isra', verse 70)

Therefore, what the author was trying to convey in the above expression text is the advantage of Yaqut compared to other precious stones such as the glory of humans is more than all other creatures of Allah SWT if that human believes, is god-fearing and performs good deeds as commanded by Allah in the al-Quran and the sunnah of the Prophet PBUH. The MIS author used the symbolism of the Yaqut precious stone to convey this message by comparing with other precious stones. The precious stones are, Lu'lu', Zumurrud, Marjan, Zabarjad, Aqiq and Fayruzaj. According to Sulaiman (1989) all these precious stones are characters for those who have value and high position in a society. The beauty and exquisiteness found in the precious stones make it very valuable and special. This research found that the usage of this symbol which was combined with other literary elements has a significant effect in portraying the personage of any individual in the community especially scholars, leaders, literary experts and so forth.

\section{Conclusion}

The use of symbols by the author of MIS is one of the features that can be seen in the expressive texts of the works of MIS. The author had used the flowers Ward, Yasamin, Narjis and the fragrances Zabad and Za'faran, the utrujjah fruit and precious stones such as Yaqut as symbols of character, attitude, morality, behaviour and human personality. The research findings summarise that the author of MIS used the elements of symbolism appropriate to the narrative of his five maqamat based on the context of time, place, tradition and culture of Arab society at that time. The findings show that these symbolic elements are used as a medium or way (wasilah) to convey the author's messages and ideas of the MIS author to the reading audience and the community. In the five maqamat stories written by al-Sayutiy, several functions have been identified for the use of the symbolic elements. The diversity of functions is summarised by the analysis of the meaning of the context and the co-text performed on the speech, which contained symbols such as flowers, fragrances, fruits and precious stones. All these symbols have various functions such as showing the bad attitude of rulers, criticising the attitude of members of the society, avoiding punishment by the rulers, expressing discomfort of the MIS author about the political situation and portraying the character and personality of an individual. From the point of view of the various functions of symbolism, in addition to the characters and attitudes of some governors and rulers discussed in this article, the researcher could, for example, explore the current situation, traditions and culture surrounding this era in this MIS. 


\section{References}

Anqar, M. (2017). Alantologia.com. Retrieved March 20, 2020, from Alantologia : http://alantologia.com/page/22667/

Al-Bandariy, A. G. S., \& Zaghlul, M. S. B. (1986). Maqamat Imam al-Suyutiy. Beirut: Darul Kutub Al-Ilmiyyah.

Al-Damin, H. S. (1979). Nazariyyah al-Nazm; Tarikh wa Taaawwur. Manshurat Wizarah alThaqafah Wa al-Iklam.

Al-Darubiy, S. M. (2001). Sharh Maqamat al-Suyutiy. Beirut: Muassasah al-Risalah.

Al-Ghubariy, I. (2013). Maqamat al-Suyutiy: Dirasah Fi Fan al-Maqamah al-Misriyyah. Kaherah: Dar al-Kutub Wa al-Wathaiq al-Qawmiyyah.

Al-Hasanat, A. A. (2013). Al-Hayah al-Ilmiyyah Fi al-Mujtamak al-Mamlukiy Min Khilal Maqamat al-Suyutiy. Muktah: Universiti Muktah.

Al-Jurjaniy, A. Q. (1994). Dalail al-I'jaz. Revised by Muhammad Rashid Ridha. Beirut: Dar alMa'rifah.

Al-Samarra'iy, F. S. (2009). Al-Maaniy al-Nahwiy. Amman: Dar al-Fikr Nashirun Wa Muwazziun.

Al-Shak'ah, M. (1981). Jalal al-Din al-Suyutiy. Kaherah: Matbaah Mustafa al-Bab al-Halabiy.

Al-Suyutiy, J. A. R. (2005). Al-Jami' al-Kabir. Kaherah: Al-Azhar al-Sharif.

Al-Suyutiy, J. A. R. (2008). Al-Rahmah fi al Tibb wa al-Hikmah. Beirut: Darul Arqam.

Darwish, A. (2008). Dirasah al-Uslub Bayna al-Muasirah Wa al-Turath. Kaherah: Dar Gharib Li al-Tibaah Wa al-Nashr Wa al-Tawzik.

Dayf, S. (2000). Al-Fann Wa Mazahibu-hu Fi al-Nathr al-Arabiy. Kaherah: Dar al- Maarif.

Diaul, K. (2018). Ekokritik Sastra Pada Novel Rahasia Pelangi Karya Riawani Elyta dan Sabrina Ws. (Bachelor of Education thesis) Universitas Muhammadiyah Makassar.

Hasan, M. R. (1974). Athar al-Maqamah Fi Nashati al-Qissah al-Misriyyah al-Hadithiyyah. Kaherah: Al-Hayah al-Miariyyah al-Amah Li al-Kitab.

Ibn Khallikan, S. A. M. (1994). Wafayat al-A'yan Wa Anba'u Abna'u al-Zaman. Beirut: Dar alSadir Li al-Tiba'ah Wa al-Nashr.

Ibn Manzur, M. M. (2003). Lisan al-Arab. Beirut: Dar al-Fikr.

Lashin, A. F. (1980). Al-Tarakib al-Nahwiyyah Min al-Wujhati al-Balaghiyya Inda Abd al-Qahir. Riyad: Dar al-Marikh Li al-Nashr.

Maharam, M. (2015). Isu-isu Alam Sekitar Dalam Sastera: Analisis Novel Ramlee Awang Murshid. Jurnal Pengajian Melayu Jilid 15: 886-120.

Marsot, A. L. S. (1985). A Short History of Modern Egypt. London: Cambridge University Press.

Basri, N. H. A. K. (2005). Jurnal Pengajian Melayu, Jilid 16: 37-54.

Salim, M. R. (1962). Așr Salatin al-Mamlik wa Nitajuhu al-lilmi wa al-Adabi. Kaherah: Maktabatu al-Adab.

Salinah, J. (2017). Unsur Alam Dan Masyarakat Dalam Teks Terjemahan Bahasa Melayu Surah Ar-Rahman. International Journal of the Malay World and Civilization 5(3): 1-23.

Sulaiman, T. H. (1989). Jalal ad-Din al-Suyutiy: Asrohu Wa Hayatuhu Wa Atharohu Wa Juhuduhu Fi al-Dars al-Lughawiy. Beirut: Al-Maktab Al-Islamiy.

Uqaiyyib, I. A. (2018). Maqamat Jalal al-Din al-Suyutiy: Dirasah Naqdiyyah. Al- Dirasat alIslamiyyah, 150-173.

Wellek, R., \& Warren, A. (1995). Teori Kesusasteraan. Jakarta: Gramedia Pustaka Utama.

Zurinah, H. (2010). Unsur Alam dalam Puisi Melayu. Bangi: Publisher UKM. 